\title{
Combination of conditional cash transfer program and environmental health interventions reduces child mortality: an ecological study of Brazilian municipalities
}

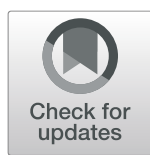

\author{
Anelise Andrade de Souza ${ }^{1 *}$ (D), Sueli Aparecida Mingoti ${ }^{2}$, Rômulo Paes-Sousa ${ }^{1}$ and Leo Heller ${ }^{1}$
}

\begin{abstract}
Background: This study aims to assess the interactive effects of Brazilian public interventions, environmental health programs (access to water, sanitation and solid waste collection) and a Conditional Cash Transfer Program (PBF), on the mortality reduction due to diarrhea and malnutrition among children under 5 years old.

Methods: The study design is ecological, with longitudinal analysis in a balanced panel. The period covered is 2006 to 2016, including 3467 municipalities from all regions of the country, which resulted in 38,137 observations. The generalized linear models were adjusted considering the Negative Binomial (NB) distribution for the number of deaths due to malnutrition and diarrhea, with fixed effects. NB models with and without zero-inflation were assessed. Subsequent interaction models were applied to assess the combined effects of the two public policies.

Results: In relation to the decline of mortality rates due to diarrhea in the municipalities, positive effect modification were observed in the presence of: high coverage of the target population by the PBF and access to water, $0.54(0.28-1.04) / 0.55(0.29-1.04)$; high coverage by the total population by the PBF and access to water, 0.97 $(0.95-1.00)$ and high coverage by the total population by the PBF and access to sanitation, 0.98 (0.97-1.00). Decline on diarrhea mortality was also observed in the joint presence of high coverage of solid waste collection and access

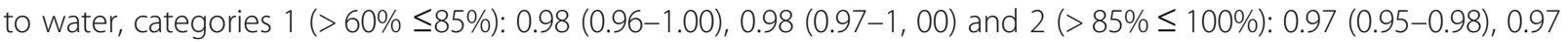
(0.95-0.99). Negative effect modification were observed for mortality due to malnutrition in the presence of simultaneous high coverage of the total population by the PBF and access to sanitation categories $1(\geq 20<50 \%$ ): $1.0061(0.9991-1.0132)$ and $2(\geq 50<100 \%): 1.0073(1.0002-1.0145)$ and high coverage of the total population by the PBF and solid waste collection, 1.0004 (1.0002-1.0005), resulting in malnutrition mortality rates increase.
\end{abstract}

Conclusion: Implementation of environmental health services and the coverage expansion by the PBF may enhance the prevention of early deaths in children under 5 years old due to diarrhea, a poverty related disease.

Keywords: Water, Sanitation, Solid waste, Social programs, Interaction, Mortality

\footnotetext{
* Correspondence: anelise.souza@fiocruz.br

'René Rachou Institute, Fiocruz Minas, Avenida Augusto de Lima, 1715, Barro Preto, Belo Horizonte, Minas Gerais, Brazil

Full list of author information is available at the end of the article
}

(C) The Author(s). 2021 Open Access This article is licensed under a Creative Commons Attribution 4.0 International License, which permits use, sharing, adaptation, distribution and reproduction in any medium or format, as long as you give appropriate credit to the original author(s) and the source, provide a link to the Creative Commons licence, and indicate if changes were made. The images or other third party material in this article are included in the article's Creative Commons. licence, unless indicated otherwise in a credit line to the material. If material is not included in the article's Creative Commons licence and your intended use is not permitted by statutory regulation or exceeds the permitted use, you will need to obtain permission directly from the copyright holder. To view a copy of this licence, visit http://creativecommons.org/licenses/by/4.0/ The Creative Commons Public Domain Dedication waiver (http://creativecommons.org/publicdomain/zero/1.0/) applies to the data made available in this article, unless otherwise stated in a credit line to the data. 


\section{Introduction}

Brazil remains among the countries with the highest levels of inequality $[1,2]$. Progress in poverty reduction achieved until 2014 began to reverse due to economic slowdown, after a period of sharp and sustained decline of poverty and inequality since $2004[1,2]$. By the period when this study was carried out, the number of families living with limited access to basic goods and services was raising. The list of deficits encompasses income, food, adequate housing, and public services, such as health, education, water, sanitation and solid waste collection [2, 3].

In relation to environmental health interventions, the main deficits that still prevail in the country are primarily related to sanitation, which is far from the necessary level of universalization [3-6]. Houses connected to piped water in premises (from water systems or wells) responds boldly for $95.6 \%$ of Brazilian households [3]. However, when considering only those holding adequate access, according to "National Basic Sanitation Plan" (PLANSAB) [3], that coverage falls to $57.7 \%$ [3]. Only $48 \%$ of the households have suitable access to the sewerage system [3]. Finally, for solid waste collection, $64.9 \%$ of the population have access to urban cleaning and proper waste management [3]. The populations most affected by these inadequate conditions are those living in peri-urban and rural areas, i.e., the poorest population groups and, consequently, the most vulnerable [7]. Thus, the economic and social vulnerability of a large part of the Brazilian population makes these groups more likely to maintain the cycle of poverty-diseases. Therefore, transformative public policies need to be successfully implemented to break that pervasive chain of events [8$11]$,, requiring an integrated set of interventions to reduce vulnerabilities and risk factors associated with health inequities $[8,11]$.

In 2003, the Brazilian government created the Bolsa Família Program (PBF) aiming to reduce economic and social vulnerability. The PBF is a Conditional Cash Transfer Program (CCT) based on three dimensions: (i) cash transfer, with values that vary according to household income and family composition; (ii) conditionality, which work as incentives for beneficiaries to increase access to public health, social assistance and education services; (iii) complementary actions, which refer to other social programs offered to PBF beneficiaries [12]. In the short term, the main objective of this Program was poverty alleviation and improvement of food security [13]. The Program started in 2003 covering 3.6 million families, jumping to 11.2 million families in 2006. In 2019, all 5570 Brazilian municipalities had already implemented the PBF, benefiting 13.8 million families [14, 15].

Intersectoral social policies can result in gains for the population as a consequence of a better organization of the public offer. That is reflected in logistics improvement and better territorial focus [16].

In environmental health, the study of interactive effects with other interventions are important for assessing the combined effects of public interventions to increase the access to quality water, adequate sanitation and collection of solid waste. The extent to which improvements on health, education, social assistance and nutrition combined with interventions in water and sanitation still requires further development in a variety of contexts [17-22]. Thus, the objective of the current study is to assess the hypothesis that, the simultaneous presence of better access conditions to environmental health interventions (water, sanitation and solid waste collection) and the access to the PBF generates an interaction effect in reducing mortality due to malnutrition and diarrhea in children under 5 years old, which are responsible for significant number of deaths in Brazil, especially in the Northeast and North regions of the country [23-25].

\section{Methods \\ Study design}

This research is framed as an ecological design with exploratory and analytical analysis. The design allows for assessing the progress of the rates of an event in different population groups and to assess the association between the average level of exposure and the rates of an event between different population groups, over time [26].

In the current study, data from 3467 Brazilian municipalities were observed for each year in the 2006-2016 period. Municipalities, from different regions of the country, were followed in all 11 years according to their geographical delimitation in the beginning of the observation. New municipalities that emerged in the observed period were treated in the level of geographical aggregation presented in 2006. Thus, there is a delineation in balanced panel data, with the municipality being the unit of analysis resulting on 38,137 observations.

In this way, it was possible to perform a longitudinal study to assess the temporal changes of mortality rates due to malnutrition and diarrhea. Furthermore, association between the average exposure to independent variables (access to PBF and environmental health variables), and mortality rates of children under 5 years old was investigated. Finally, the design allowed for assess interaction between independent variables, mainly access to PBF and environmental health variables.

\section{Inclusion criteria for municipalities}

In 2006, the starting year of the study, Brazil presented 5560 municipalities. All municipalities at the time presented: (i) adequacy of vital statistics data [27, 28]; (ii) 
annual data of mortality due to diarrhea and malnutrition for children under 5 years old; (iii) data on coverage of the target population and municipal total by the PBF; (iv) data on coverage by environmental health services (water, sanitation and solid waste collection) for the years 2000 and 2010.

To assess the adequacy of vital statistics data, a multidimensional criterion was applied [27, 28]. This criterion was used based on the following indicators, using their means and Confidence Intervals for the years 2006 to 2008: (i) Age-Standardized Mortality Rate (SMR); (ii) relative average deviation from SMR; (iii) ratio of informed and estimated live births; (iv) relative average deviation in birth rates; $(\mathrm{v})$ proportion of deaths classified as ill-defined causes. Subsequently, according to the assumed criterion, the municipalities were classified according to data reliability as "satisfactory", "unsatisfactory" and "deficient". Only municipalities classified as "satisfactory" were selected for the study. The period used for assessing the data reliability was 2006 to 2008. The same classification of the municipalities was replicated for the years 2009 to 2016 [27, 28].

\section{Outcome variables}

The study variables were selected according to Fig. 1, which comprise two main pathways that can affect the health outcomes of interest, mortality due to malnutrition and diarrhea in children under 5 years old. The groups of selected causes of mortality were created by aggregating the categories of the International Statistical Classification of Diseases and Health-Related Problems Tenth revision (ICD-10). Groups A00 - A04 and A06 A09 were used for mortality due to diarrhea. Those are also classified as Diseases Related to Inadequate Environmental Sanitation (DRSAI) [30]. Categories E40 to E46 were used for mortality due to malnutrition.

\section{Independent variables and other covariates}

Regarding to the independent variables: (i) adequate access to water refers to drinking water from public network, well or individual well; (ii) adequate access to sanitation refers to wastewater collection by sewerage or disposal in a septic tank; (iii) adequate solid waste collection refers to direct collection from the household. PLANSAB [3, 31] and the Joint Monitoring Program (JMP) [32] guidelines were used as references for choosing the independent variables, considering the Brazilian context and the data availability.

For the PBF, two variables were used: proportion of total population covered in the municipality by the Program and proportion of target population (poor and extremely poor families) covered in the municipality by the PBF. Eligible families are those that are classified as poor (per capita monthly income of $\mathrm{R} \$ 89$ to $\mathrm{R} \$ 178$ ) or extremely poor (per capita monthly income of up to $\mathrm{R} \$ 89)[12,14,15]$.

Finally, the set of covariables used in this study for controlling confounding effects [22, 33-42] are: (i) per capita monthly income of the municipal population (in Brazilian Reais); (ii) proportion of literate people older than 15 years of age; (iii) proportion of population covered by the Family Health Strategy (ESF), an active door-to-door component of the primary health care policy in the country; (v) proportion of population living in urban areas. The mentioned variables are associated with better wellbeing and access to health services.

\section{Data source}

Data were gathered from the following institutions: (i) Ministry of Health (Mortality Information System/SIM) [43]; (ii) Ministry of Social Development (Social Information Matrix/MIS) [44]; (iii) Brazilian Institute of Geography and Statistics/IBGE (Population censuses of 2000 and 2010, and intercensal estimates) [45] (Table 1).

\section{Data analysis}

Descriptive analyses were carried out for the observed municipalities. For statistical inferences, the generalized linear model was adjusted with the Negative Binomial distribution (without and with zero-inflated) to control the overdispersion in the regression models [48-51].

The final regression model was chosen according to the following parameters: (i) Akaike Information Criterion (AIC); (ii) Bayesian Information Criterion (BIC); (iii) better ability to predict the frequency of deaths; (iv) better adjustment of deviations (Deviance and Pearson); (v) possibility of assessing the interactions of interest in the current study.

Most of the study variables were assessed as continuous variables. The variables "Proportion of the target population covered by the PBF" and "access to water" and access to sanitation" were assessed in a categorical manner. The cutoff points used for the categorization were chosen by studying the sample distribution of the values of the variables using the quartiles of the distribution as the main reference, being: (i) proportion of the target population covered by the PBF $<90 \%$ (category 0 ), $\geq 90$ and $<100 \%$ (category 1), $100 \%$ (category 2); (ii) coverage of access to water: 0 to $\leq 60 \%$ (category 0 ), > $60 \%$ and $\leq 85 \%$ (category 1 ), $>85 \%$ and $\leq 100 \%$ (category 2 ); (iii) coverage of access to sanitation: $<20 \%$ (category 0 ), $\geq 20$ and $<50 \%$ (category 1 ), $\geq 50 \%$ and $\leq 100 \%$ (category 2).

Also included in the models were terms of interaction between: (i) proportion of population and proportion of target population covered by the PBF and "access to water"; (ii) proportion of population and proportion of target population covered by the PBF and "access to 


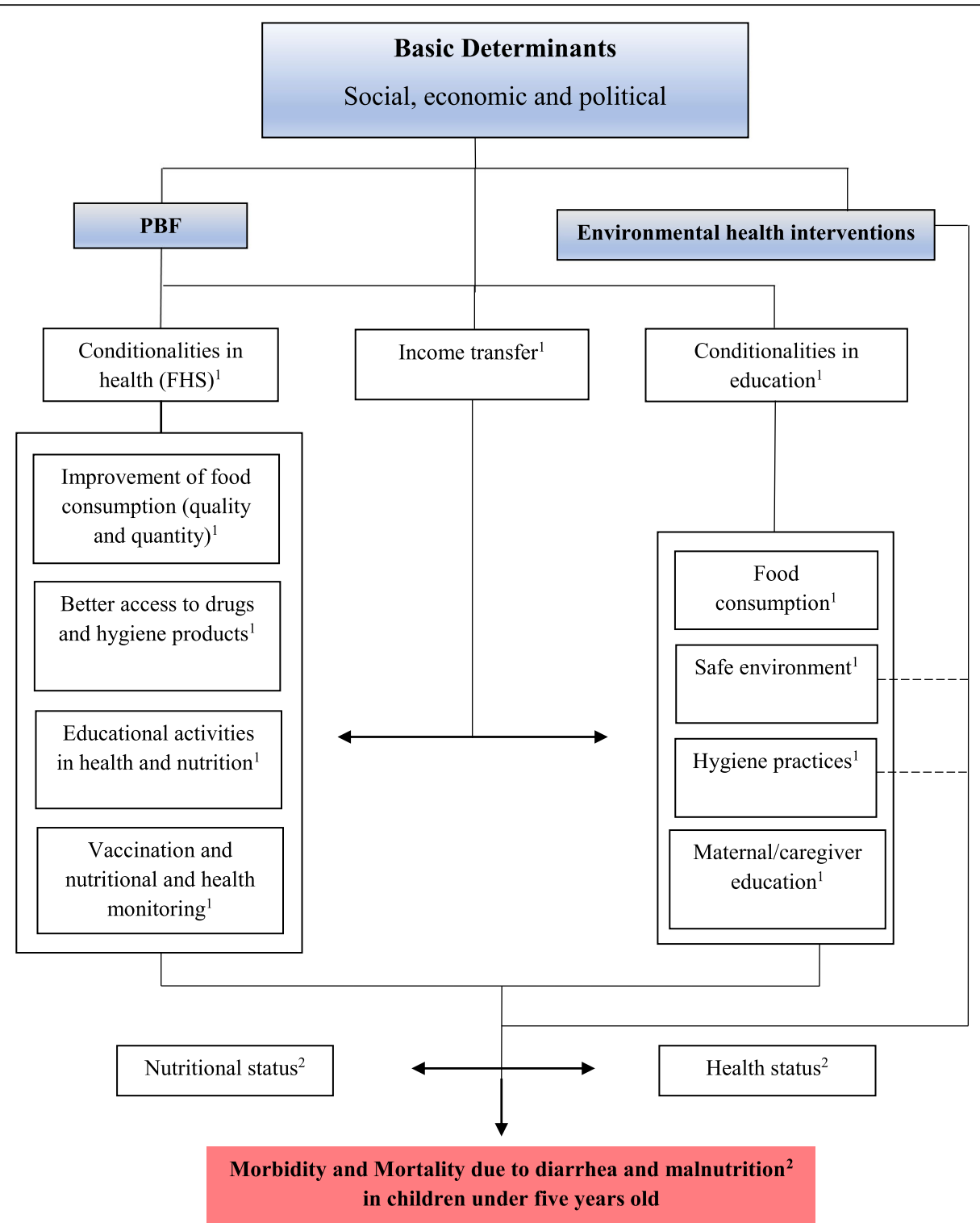

Fig. 1 Mechanisms that link the PBF and access to environmental health interventions to children's nutritional and health outcomes. Source: adapted from Groot et al. [29], and Rasella et al. [22]. ' Underlying determinants. ${ }^{2}$ Outcome

sanitation"; (iii) proportion of population and proportion of target population covered by the PBF and "access to solid waste collection", in addition to terms of interaction between the variables related to accesses to water, sanitation and solid waste collection.

The significance level of $25 \%$ ( $p$-value $=0.25)$ obtained in the univariate analyzes was used as the criterion for selecting variables to compose the multivariate regression models. In these, a significance level of $5 \%(p<0.05)$ was used for the variables to remain in the final models. Finally, the significance level of $10 \%(p<0.10)$ obtained in the interaction models was used for classifying the observed effects as significant.
Microsoft Office Excel 2010 software was used for the database construction. The R (version 3.0.2) 2013 statistical package (The R Foundation for Statistical Computing) was used for the performing descriptive and inferential analyses.

\section{Results}

\section{Descriptive statistics}

Table 2 shows descriptive statistics for the Brazilian municipalities in relation to variables and period of interest. Among the municipalities, 3526 (out of 5560) presented adequacy of vital statistics [27, 28]. After applying the other inclusion criteria, 3467 municipalities (62.35\%) remained in the study. Mortality rates due to 
Table 1 Variables available in the information systems and availability period

\begin{tabular}{|c|c|c|}
\hline Variables & Data source/information system & Period \\
\hline $\begin{array}{l}\text { Deaths for diarrhea }{ }^{a}(A 00-A 04 \text { and } A 06-A 09)^{b} \text { and for malnutrition }(E 40-E 46)^{b} \\
\text { and number of children under the age of five }\end{array}$ & $\begin{array}{l}\text { Mortality Information System (SIM) / Informatics Department of the } \\
\text { Unified Health System (SUS) (DATASUS) }\end{array}$ & $\begin{array}{l}\text { Years } 2006 \text { to } \\
2016\end{array}$ \\
\hline Beneficiary families of the Bolsa Família Program (PBF) & $\begin{array}{l}\text { Social Information Matrix (MIS) / Information Evaluation and } \\
\text { Management Service (SAGI) }\end{array}$ & $\begin{array}{l}\text { Years } 2006 \text { to } \\
2016\end{array}$ \\
\hline Average size of beneficiary families & MIS / SAGI & $\begin{array}{l}\text { Years } 2007 \\
\text { and } 2010\end{array}$ \\
\hline Families eligible for the Bolsa Família Program (PBF) & MIS / SAGI & $\begin{array}{l}\text { Years } 2006 \text { to } \\
2016\end{array}$ \\
\hline $\begin{array}{l}\text { Number of households with coverage for water and sanitation services and } \\
\text { number of municipal households }\end{array}$ & CENSO / IBGE & $\begin{array}{l}\text { Years } 2000 \\
\text { and } 2010^{c}\end{array}$ \\
\hline Population exposed to solid waste collection and total municipal population & CENSO / IBGE & $\begin{array}{l}\text { Years } 2000 \\
\text { and } 2010^{c}\end{array}$ \\
\hline Per capita monthly income & CENSO/IBGE & $\begin{array}{l}\text { Years } 2000 \\
\text { and } 2010^{c}\end{array}$ \\
\hline $\begin{array}{l}\text { Proportion of individuals without basic literacy among the population aged } 15 \text { and } \\
\text { over }\end{array}$ & CENSO / IBGE & $\begin{array}{l}\text { Years } 2000 \\
\text { and } 2010^{c}\end{array}$ \\
\hline Urbanization rate & IBGE & $\begin{array}{l}\text { Years } 2000 \\
\text { and } 2010^{c}\end{array}$ \\
\hline $\begin{array}{l}\text { Population served by primary care related to the Family Health Strategy (FHS) and } \\
\text { total municipal population }\end{array}$ & Primary Care Information System (SIAB) / DATASUS & $\begin{array}{l}\text { Years } 2006 \text { to } \\
2016\end{array}$ \\
\hline
\end{tabular}

Table 2 Descriptive measures of mortality rates by years of study and municipalities selected - Brazil $(N=3467)$

$\begin{array}{llllllllllll}2006 & 2007 & 2008 & 2009 & 2010 & 2011 & 2012 & 2013 & 2014 & 2015 & 2016 & \begin{array}{l}\text { Percentage } \\ \text { Change 2006- } \\ 2016\end{array}\end{array}$

\begin{tabular}{|c|c|c|c|c|c|c|c|c|c|c|c|c|}
\hline \multicolumn{13}{|l|}{ Mortality } \\
\hline Due to malnutrition & $\begin{array}{l}0.53 \\
(2.61)\end{array}$ & $\begin{array}{l}0.44 \\
(2.52)\end{array}$ & $\begin{array}{l}0.35 \\
(2.14)\end{array}$ & $\begin{array}{l}0.36 \\
(2.37)\end{array}$ & $\begin{array}{l}0.32 \\
(2.38)\end{array}$ & $\begin{array}{l}0.26 \\
(1.71)\end{array}$ & $\begin{array}{l}0.28 \\
(2.32)\end{array}$ & $\begin{array}{l}0.25 \\
(1.85)\end{array}$ & $\begin{array}{l}0.23 \\
(1.75)\end{array}$ & $\begin{array}{l}0.25 \\
(1.97)\end{array}$ & $\begin{array}{l}0.19 \\
(1.43)\end{array}$ & $-64.15 \%$ \\
\hline Due to diarrhea & $\begin{array}{l}0.12 \\
(1.02)\end{array}$ & $\begin{array}{l}0.09 \\
(1.02)\end{array}$ & $\begin{array}{l}0.09 \\
(0.88)\end{array}$ & $\begin{array}{l}0.07 \\
(0.81)\end{array}$ & $\begin{array}{l}0.07 \\
(0.75)\end{array}$ & $\begin{array}{l}0.08 \\
(0.91)\end{array}$ & $\begin{array}{l}0.07 \\
(0.97)\end{array}$ & $\begin{array}{l}0.04 \\
(0.52)\end{array}$ & $\begin{array}{l}0.05 \\
(0.70)\end{array}$ & $\begin{array}{l}0.07 \\
(1.18)\end{array}$ & $\begin{array}{l}0.07 \\
(1.11)\end{array}$ & $-41.66 \%$ \\
\hline $\begin{array}{l}\text { Proportion of coverage of the } \\
\text { total population by PBF }\end{array}$ & $\begin{array}{l}31.2 \% \\
(18.6)\end{array}$ & $\begin{array}{l}31.1 \% \\
(19.1)\end{array}$ & $\begin{array}{l}28.2 \% \\
(18.0)\end{array}$ & $\begin{array}{l}30.8 \% \\
(18.5)\end{array}$ & $\begin{array}{l}31.2 \% \\
(19.0)\end{array}$ & $\begin{array}{l}32.4 \% \\
(20.6)\end{array}$ & $\begin{array}{l}33.2 \% \\
(21.2)\end{array}$ & $\begin{array}{l}32.4 \% \\
(21.0)\end{array}$ & $\begin{array}{l}32.1 \% \\
(21.8)\end{array}$ & $\begin{array}{l}30.5 \% \\
(20.6)\end{array}$ & $\begin{array}{l}29.3 \% \\
(20.8)\end{array}$ & $-6.09 \%$ \\
\hline $\begin{array}{l}\text { Proportion of coverage of the } \\
\text { target population by the PBF }\end{array}$ & $\begin{array}{l}87.2 \% \\
(15.9)\end{array}$ & $\begin{array}{l}86.8 \% \\
(15.2)\end{array}$ & $\begin{array}{l}83.1 \% \\
(16.5)\end{array}$ & $\begin{array}{l}90.8 \% \\
(12.9)\end{array}$ & $\begin{array}{l}92.3 \% \\
(12.3)\end{array}$ & $\begin{array}{l}93.2 \% \\
(13.1)\end{array}$ & $\begin{array}{l}94.4 \% \\
(12.1)\end{array}$ & $\begin{array}{l}94.3 \% \\
(12.7)\end{array}$ & $\begin{array}{l}91.9 \% \\
(14.6)\end{array}$ & $\begin{array}{l}91.7 \% \\
(15.1)\end{array}$ & $\begin{array}{l}71.7 \% \\
(34.0)\end{array}$ & $-17.77 \%$ \\
\hline $\begin{array}{l}\text { Proportion of sanitation } \\
\text { coverage }\end{array}$ & $\begin{array}{l}39.3 \% \\
(29.7)\end{array}$ & $\begin{array}{l}40.0 \% \\
(29.7)\end{array}$ & $\begin{array}{l}40.8 \% \\
(29.8)\end{array}$ & $\begin{array}{l}41.5 \% \\
(30.0)\end{array}$ & $\begin{array}{l}42.2 \% \\
(30.3)\end{array}$ & $\begin{array}{l}43.2 \% \\
(30.6)\end{array}$ & $\begin{array}{l}44.3 \% \\
(30.9)\end{array}$ & $\begin{array}{l}45.5 \% \\
(31.2)\end{array}$ & $\begin{array}{l}46.7 \% \\
(31.6)\end{array}$ & $\begin{array}{l}48.0 \% \\
(31.9)\end{array}$ & $\begin{array}{l}49.4 \% \\
(32.3)\end{array}$ & $25.70 \%$ \\
\hline Proportion of water coverage & $\begin{array}{l}87.3 \% \\
(14.2)\end{array}$ & $\begin{array}{l}87.2 \% \\
(14.0)\end{array}$ & $\begin{array}{l}87.1 \% \\
(13.9)\end{array}$ & $\begin{array}{l}87.0 \% \\
(13.9)\end{array}$ & $\begin{array}{l}86.9 \% \\
(14.0)\end{array}$ & $\begin{array}{l}86.8 \% \\
(14.1)\end{array}$ & $\begin{array}{l}86.7 \% \\
(14.2)\end{array}$ & $\begin{array}{l}86.6 \% \\
(14.3)\end{array}$ & $\begin{array}{l}86.5 \% \\
(14.5)\end{array}$ & $\begin{array}{l}86.3 \% \\
(14.6)\end{array}$ & $\begin{array}{l}86.2 \% \\
(14.8)\end{array}$ & $-1.26 \%$ \\
\hline $\begin{array}{l}\text { Proportion of solid waste } \\
\text { collection }\end{array}$ & $\begin{array}{l}63.3 \% \\
(22.3)\end{array}$ & $\begin{array}{l}64.8 \% \\
(21.7)\end{array}$ & $\begin{array}{l}66.2 \% \\
(21.3)\end{array}$ & $\begin{array}{l}67.7 \% \\
(20.9)\end{array}$ & $\begin{array}{l}69.2 \% \\
(20.5)\end{array}$ & $\begin{array}{l}71.0 \% \\
(20.3)\end{array}$ & $\begin{array}{l}73.0 \% \\
(20.1)\end{array}$ & $\begin{array}{l}74.9 \% \\
(19.8)\end{array}$ & $\begin{array}{l}76.8 \% \\
(19.6)\end{array}$ & $\begin{array}{l}78.7 \% \\
(19.2)\end{array}$ & $\begin{array}{l}80.6 \% \\
(18.9)\end{array}$ & $27.33 \%$ \\
\hline $\begin{array}{l}\text { Proportion of coverage of the } \\
\text { total population by the FHS }\end{array}$ & $\begin{array}{l}72.2 \% \\
(31.1)\end{array}$ & $\begin{array}{l}74.9 \% \\
(29.7)\end{array}$ & $\begin{array}{l}79.7 \% \\
(29.1)\end{array}$ & $\begin{array}{l}80.5 \% \\
(28.3)\end{array}$ & $\begin{array}{l}82.0 \% \\
(27.6)\end{array}$ & $\begin{array}{l}83.0 \% \\
(27.1)\end{array}$ & $\begin{array}{l}83.3 \% \\
(26.8)\end{array}$ & $\begin{array}{l}84.3 \% \\
(25.3)\end{array}$ & $\begin{array}{l}86.2 \% \\
(22.8)\end{array}$ & $\begin{array}{l}88.3 \% \\
(20.9)\end{array}$ & $\begin{array}{l}88.5 \% \\
(20.9)\end{array}$ & $22.58 \%$ \\
\hline Urbanization rate (\%) & $\begin{array}{l}62.6 \% \\
(21.5)\end{array}$ & $\begin{array}{l}62.9 \% \\
(21.3)\end{array}$ & $\begin{array}{l}63.3 \% \\
(21.1)\end{array}$ & $\begin{array}{l}63.6 \% \\
(21.0)\end{array}$ & $\begin{array}{l}64.0 \% \\
(20.9)\end{array}$ & $\begin{array}{l}64.5 \% \\
(20.8)\end{array}$ & $\begin{array}{l}65.1 \% \\
(20.8)\end{array}$ & $\begin{array}{l}65.7 \% \\
(20.8)\end{array}$ & $\begin{array}{l}66.4 \% \\
(20.8)\end{array}$ & $\begin{array}{l}67.0 \% \\
(20.8)\end{array}$ & $\begin{array}{l}67.7 \% \\
(20.9)\end{array}$ & $8.15 \%$ \\
\hline $\begin{array}{l}\text { Per capita monthly income in } \\
\text { reais }(R \$)^{a}\end{array}$ & $\begin{array}{l}353.9 \\
(208.5)\end{array}$ & $\begin{array}{l}368.2 \\
(218.3)\end{array}$ & $\begin{array}{l}365.9 \\
(216.9)\end{array}$ & $\begin{array}{l}357.8 \\
(210.0)\end{array}$ & $\begin{array}{l}514.4 \\
(259.2)\end{array}$ & $\begin{array}{l}370.8 \\
(217.8)\end{array}$ & $\begin{array}{l}369.1 \\
(217.0)\end{array}$ & $\begin{array}{l}376.2 \\
(222.2)\end{array}$ & $\begin{array}{l}379.5 \\
(224.1)\end{array}$ & $\begin{array}{l}396.0 \\
(234.3)\end{array}$ & $\begin{array}{l}383.0 \\
(226.6)\end{array}$ & $8.22 \%$ \\
\hline Proportion of literate individuals & $\begin{array}{l}71.0 \% \\
(11.0)\end{array}$ & $\begin{array}{l}70.9 \% \\
(10.6)\end{array}$ & $\begin{array}{l}70.0 \% \\
(9.9)\end{array}$ & $\begin{array}{l}68.5 \% \\
(10.2)\end{array}$ & $\begin{array}{l}67.0 \% \\
(10.2)\end{array}$ & $\begin{array}{l}74.6 \% \\
(7.0)\end{array}$ & $\begin{array}{l}73.0 \% \\
(7.4)\end{array}$ & $\begin{array}{l}71.4 \% \\
(7.7)\end{array}$ & $\begin{array}{l}69.6 \% \\
(8.1)\end{array}$ & $\begin{array}{l}67.7 \% \\
(8.6)\end{array}$ & $\begin{array}{l}65.6 \% \\
(9.1)\end{array}$ & $-7.61 \%$ \\
\hline
\end{tabular}

Data refer to the mean and (standard deviation). For income ${ }^{a}$, the median was considered. Causes of mortality in children under 5 years old are defined according to the International Classification of Diseases (ICD), 10th revision: diarrheal diseases (A00, A01, A02, A03, A04, A06-08) and malnutrition diseases (E40 - E46). Mortality rates are shown in the table for every 10 thousand children up to 5 years old. N Number of municipalities. PBF Bolsa Família Program. FHS Family Health Strategy 
malnutrition and diarrhea were reduced between 2006 and 2016 by 64.15 and $41.66 \%$, respectively.

The PBF and access to water coverages showed a decline when comparing the first and last year of the observed period. In turn, the variable related to municipal sanitation coverage increased over the years by $25.70 \%$, when comparing the years 2006 and 2016. However, the coverage was persistently below to $50,00 \%$ accross the observed period.

Tables S1 to S5 (supplementary material) show descriptive statistics according to Brazilian regions. The regional distribution of municipalities included in this study is as follow: 1163 (33.54\%) from the Northeast, 1037 (29.91\%) from the Southeast, 777 (22.42\%) from the South, 302 (8.71\%) from Midwestern region and 188 (5.42\%) from the Northern region. Between 2006 and 2016, all regions showed mortality rates decline due to malnutrition and diarrhea. The highest mortality rates declines were observed in the Southeastern (malnutrition) and Southern (diarrhea) regions.

In the longitudinal observation of the period, the Northern region presented the worst average mortality rates due to malnutrition $(0.65 / 10,000)$ and diarrhea $(0.21 / 10,000)$, followed by mortality due to malnutrition in the Northeastern region $(0.47 / 10,000)$. Regarding the independent variables, Midwestern, Southeastern and Southern regions presented declines in the in the proportion of population covered by the PBF. Midwestern, Northeastern, Southeastern and Southern regions presented declines in the proportion of target population covered by the PBF. All regions showed increased sanitation coverage between the first and last year of studied period. However, only the Southeastern region presented coverage above $75 \%$ in 2016 . The Northeast was the only region to show an increase in sanitation coverage when comparing the years 2006 and 2016. However, it remained in the last place among regions of the country.

\section{Inferential statistics}

Table 3 shows the estimates of the Incidence Rate Ratios (IRR) and a 95\% confidence interval, derived from the adjustments of the multivariate models of Negative Binomial regression with and without zero-inflated, for the average mortality rates due to malnutrition. The results of these models show a negative effect, with an increase in the average mortality rates due to malnutrition, when high coverage of the total municipal population by the PBF is present. Table 4, in turn, shows the IRR and a 95\% confidence interval, derived from the adjustments of the multivariate models of Negative Binomial regression with and without zero-inflated, for the average mortality rates due to diarrhea. The results also show a negative effect of the variable coverage of the total population by the PBF, as well as a positive effect, with a

Table 3 IRR Results - Fixed-effects Negative Binomial (NB) regression model to assess mortality due to malnutrition in children under 5 years old

\begin{tabular}{lll}
\hline & $\begin{array}{l}\text { NB regression model without zero inflation } \\
\text { IRR }^{\mathbf{a}}(\mathbf{C l}-\mathbf{9 5} \%) \boldsymbol{p} \text {-value }\end{array}$ & $\begin{array}{l}\text { NB regression model with zero inflation } \\
\text { IRR }^{\mathbf{a}}(\mathbf{C l}-\mathbf{9 5} \%) \boldsymbol{p} \text {-value }\end{array}$ \\
\hline Bolsa Família Program (PBF) total & $1.022(1.018-1.026)<2 \mathrm{e}-16$ & $1.016(1.011-1.021) 6.04 \mathrm{e}-11$ \\
Literacy population 15 years or older & $0.984(0.978-0.991) 2.71 \mathrm{e}-06$ & $0.987(0.980-0.993) 7.54 \mathrm{e}-05$ \\
Population & $0.949(0.912-0.989) 0.00977$ & $0.882(0.841-0.926) 4.17 \mathrm{e}-07$ \\
Northeast Region & $0.512(0.450-0.584)<2 \mathrm{e}-16$ & $0.485(0.416-0.564)<2 \mathrm{e}-16$ \\
Midwest Region & $1.038(0.855-1.260) 0.70382$ & $1.975(1.443-2.702) 2.11 \mathrm{e}-05$ \\
Southeast Region & $0.383(0.322-0.456)<2 \mathrm{e}-16$ & $0.342(0.273-0.427)<2 \mathrm{e}-16$ \\
South Region & $0.381(0.303-0.476)<2 \mathrm{e}-16$ & $0.334(0.239-0.466) 1.24 \mathrm{e}-10$ \\
Year 2007 & $0.932(0.797-1.091) 0.38650$ & $0.908(0.775-1.063) 0.22289$ \\
Year 2008 & $0.762(0.644-0.901) 0.00157$ & $0.744(0.628-0.880) 0.00056$ \\
Year 2009 & $0.670(0.564-0.794) 4.35 \mathrm{e}-06$ & $0.657(0.554-0.780) 1.64 \mathrm{e}-06$ \\
Year 2010 & $0.571(0.478-0.681) 6.91 \mathrm{e}-10$ & $0.561(0.469-0.671) 2.13 \mathrm{e}-10$ \\
Year 2011 & $0.566(0.468-0.683) 4.09 \mathrm{e}-09$ & $0.560(0.463-0.677) 2.14 \mathrm{e}-09$ \\
Year 2012 & $0.452(0.370-0.551) 6.52 \mathrm{e}-15$ & $0.444(0.364-0.543) 2.01 \mathrm{e}-15$ \\
Year 2013 & $0.454(0.372-0.552) 4.28 \mathrm{e}-15$ & $0.457(0.375-0.557) 8.29 \mathrm{e}-15$ \\
Year 2014 & $0.440(0.360-0.535) 3.69 \mathrm{e}-16$ & $0.438(0.359-0.534) 3.71 \mathrm{e}-16$ \\
Year 2015 & $0.408(0.332-0.499)<2 \mathrm{e}-16$ & $0.403(0.328-0.494)<2 \mathrm{e}-16$ \\
Year 2016 & $0.373(0.302-0.459)<2 \mathrm{e}-16$ & $0.378(0.306-0.466)<2 \mathrm{e}-16$ \\
\hline
\end{tabular}

Model without zero inflation: AIC: 15248. BIC: 15429.37. 2 x loglik: - 15,210,437. Zero inflation model: AIC: 15190. BIC: 15420. 2 x log-lik: - 15,134

The comparison references of the models refer to the regions: North region and for the year: 2006

${ }^{\mathrm{a}}$ Ratio for incidence rates 
Table 4 IRR Results - Fixed-effects Negative Binomial (NB) regression model to assess mortality due to diarrhea in children under 5 years old

\begin{tabular}{|c|c|c|}
\hline & $\begin{array}{l}\text { NB regression model without zero inflation } \\
\text { IRR }^{\mathrm{a}}(\mathrm{Cl}-95 \%) p \text {-value }\end{array}$ & $\begin{array}{l}\text { NB regression model with zero inflation } \\
\text { IRR }^{\mathrm{a}}(\mathrm{Cl}-95 \%) p \text {-value }\end{array}$ \\
\hline \multicolumn{3}{|l|}{ Bolsa Família Program (PBF) target } \\
\hline$\geq 90 \% \leq 99.9 \%$ (category 1) & $0.7058(0.5427-0.9113) 0.007981$ & $0.7363(0.5591-0.9695) 0.029240$ \\
\hline $100 \%$ (category 2) & $0.8203(0.6562-1.0248) 0.080057$ & $0.9039(0.7165-1.1404) 0.394133$ \\
\hline Bolsa Família Program (PBF) total & $1.0220(1.0118-1.0322) 1.71 \mathrm{e}-05$ & $1.0218(1.0117-1.0320) 2.20 \mathrm{e}-05$ \\
\hline \multicolumn{3}{|l|}{ Environmental Health } \\
\hline \multicolumn{3}{|l|}{ Access to water } \\
\hline$>60 \% \leq 85 \%$ (category 1 ) & $0.6235(0.4666-0.8399) 0.001897$ & $0.6267(0.4678-0.8396) 0.001737$ \\
\hline$>85 \% \leq 100 \%$ (category 2) & $0.5779(0.4048-0.8221) 0.002627$ & $0.5946(0.4189-0.8440) 0.003624$ \\
\hline \multicolumn{3}{|l|}{ Access to sanitation } \\
\hline$\geq 20<50 \%$ (category 1) & $0.7927(0.6330-0.9894) 0.040499$ & $0.7579(0.5912-0.9716) 0.028718$ \\
\hline$\geq 50<100 \%$ (category 2) & $0.8501(0.6317-1.1416) 0.277095$ & $0.7152(0.5106-1.0017) 0.051177$ \\
\hline Solid waste collection & $0.9901(0.9812-0.9991) 0.030414$ & $0.9902(0.9812-0.9993) 0.035712$ \\
\hline Family Health Strategy (FHS) & $0.9980(0.9946-1.0014) 0.237284$ & $0.9952(0.9915-0.9989) 0.011344$ \\
\hline Literacy population 15 years or older & $0.9783(0.9655-0.9914) 0.001163$ & $0.9711(0.9574-0.9850) 5.32 \mathrm{e}-05$ \\
\hline Per capita income & $0.7943(0.5924-1.0666) 0.118250$ & $0.6342(0.4582-0.8776) 0.006007$ \\
\hline Urbanization rate & $1.0159(1.0072-1.0248) 0.000319$ & 1.0266 (1.0164-1.0369) 2.42e-07 \\
\hline Northeast Region & $0.3916(0.3021-0.5094) 2.39 \mathrm{e}-12$ & $0.4428(0.3367-0.5824) 5.69 \mathrm{e}-09$ \\
\hline Midwest Region & $1.0266(0.6933-1.5124) 0.892349$ & 3.0768 (1.7230-5.4945) 0.000145 \\
\hline Southeast Region & $0.4497(0.3134-0.6450) 9.49 \mathrm{e}-06$ & $0.4999(0.3439-0.7269) 0.000283$ \\
\hline South Region & $0.7451(0.4937-1.1185) 0.150701$ & $0.8881(0.5809-1.3575) 0.583517$ \\
\hline Year 2007 & $0.8551(0.6222-1.1728) 0.331941$ & $0.8528(0.6228-1.1676) 0.320511$ \\
\hline Year 2008 & $0.9136(0.6650-1.2534) 0.576897$ & $0.8999(0.6569-1.2326) 0.511081$ \\
\hline Year 2009 & $0.6731(0.4747-0.9489) 0.024212$ & $0.6729(0.4768-0.9498) 0.024283$ \\
\hline Year 2010 & $0.7823(0.5401-1.1289) 0.190924$ & $0.8082(0.5603-1.1658) 0.254591$ \\
\hline Year 2011 & $0.7859(0.5405-1.1362) 0.197112$ & $0.7646(0.5280-1.1073) 0.155411$ \\
\hline Year 2012 & $0.5942(0.3984-0.8779) 0.009309$ & $0.5859(0.3952-0.8686) 0.007778$ \\
\hline Year 2013 & $0.5577(0.3712-0.8294) 0.004322$ & $0.5424(0.3628-0.8110) 0.002877$ \\
\hline Year 2014 & $0.5122(0.3356-0.7714) 0.001381$ & $0.5077(0.3353-0.7690) 0.001372$ \\
\hline Year 2015 & $0.5507(0.3610-0.8289) 0.004266$ & $0.5439(0.3588-0.8247) 0.004133$ \\
\hline Year 2016 & $0.5837(0.3862-0.8735) 0.009270$ & $0.5719(0.3798-0.8611) 0.007449$ \\
\hline
\end{tabular}

Model without zero inflation: AIC: 5772.70. BIC: 6012.05. 2 x loglik: - 5716,685. Zero inflation model: AIC: 5746.00. BIC: 6105.05. 2 x loglik: - 5662.0 The comparison references of the models refer to the target PBF: $<90 \%$ (category 0); access to water: $\leq 60 \%$ (category 0 ); sanitation: $<20 \%$ (category 0 ); regions: North region and for the year: 2006

${ }^{\text {a }}$ Ratio for incidence rates

decrease in the average mortality rates due to diarrhea, when the target population are highly covered by the PBF in the municipalities (category 1 versus category 0 ), access to water (categories 1 and 2 versus category 0 ) and access to sanitation (categories 1 and 2 versus category 0 ).

Table 5 provides answers to the main question that served as the basis for this study. It presents the estimates of the IRR, derived from the adjustments of the multivariate models of Negative Binomial regression with and without zero-inflated, including the interaction terms significant between access to PBF and to environmental sanitation services. For the outcome of mortality due to malnutrition, the interactions between the variables were significant: (i) proportion of total population covered by the PBF and collection of solid waste; (ii) proportion of total population covered by the PBF and access to sanitation (category 1); (iii) proportion of total population covered by the PBF and access to sanitation (category 2). In turn, for the outcome of mortality due to diarrhea, the interactions between the variables were significant: (i) proportion of total population covered by 
Table 5 Results of the Fixed-effects Negative Binomial (NB) regression model to assess the interaction to the outcome of mortality due to malnutrition and diarrhea in children under 5years old

\begin{tabular}{lll}
\hline & $\begin{array}{l}\text { NB regression model without zero } \\
\text { inflation } \\
\text { Interactions }\end{array}$ & $\begin{array}{l}\text { NB regression model with zero } \\
\text { inflation } \\
\text { Interactions }\end{array}$ \\
IRR $^{\mathrm{a}}(\mathrm{Cl}-90 \%) p$-value & IRR $^{\mathrm{a}}(\mathrm{Cl}-90 \%) p$-value \\
\hline
\end{tabular}

\section{Malnutrition}

Interaction between:

PBF total

Solid waste collection ${ }^{\#}$

Interaction between:

PBF total

Access to sanitation $^{\#} \geq 20<50 \%$ (category 1 )

Interaction between:

PBF total

Access to sanitation ${ }^{\#} \geq 50<100 \%$ (category 2)

\section{Diarrhea}

Interaction between:

PBF total

Access to water $>60 \% \leq 85 \%$ (category 1 )

Interaction between:

100\% PBF target (category 2)

Access to water $>85 \% \leq 100 \%$ (category 2)

Interaction between:

PBF total

Access to sanitation $\geq 50<100 \%$ (category 2 )

Interaction between:

Access to water $>60 \% \leq 85 \%$ (category 1 ) Solid waste

collection

Interaction between:

Access to water $>85 \% \leq 100 \%$ (category 2 )

Solid waste collection
$1.0004(1.0002-1.0005) 2.56 \mathrm{e}-09$

$1.0061(0.9991-1.0132) 0.088284$

$1.0073(1.0002-1.0145) 0.045116$

$0.9774658(0.9533472-1.002195) 0.073767$

$0.9780299(0.9549282-1.001691)$

0.068526

$0.5463344(0.285883-1.044068) 0.067326$

$0.558559(0.2980557-1.046745) 0.069151$

$0.9892611(0.9764852-1.002204)$

0.103500

$0.9837505(0.9672618-1.00052) 0.057466$

$0.9892611(0.9764852-1.002204)$

0.080497

$0.9739308(0.9581343-0.9899877) 0.001545 \quad 0.9746869(0.9582469-0.991409)$ 0.003134

Malnutrition: The model comparison references refer to sanitation: <20\% (category 0 )

"The variables: solid waste collection, sanitation and access to water were not significant in multivariate analyzes. However, solid waste collection and sanitation were significant in the interaction models, according to the values presented in this Table. In the interaction models, their individual values were for: solid waste collection (IRR $0.9815 \mathrm{Cl} 0.9750-0.9880 p$-value $=2.93 \mathrm{e}-08$ ), for sanitation category 1 (IRR $0.7611 \mathrm{Cl} 0.5316-1.0897 p$-value $=0.136025)$ and for sanitation category 2 (IRR $0.7520 \mathrm{Cl} 0.5314-1.0640 p$-value $=0.107465)$

Diarrhea: The comparison references of the models refer to the target PBF: <90\% (category 0 ); access to water: $\leq 60 \%$ (category 0 ); sanitation: $<20 \%$ (category 0 )

${ }^{\text {a }}$ Ratio for incidence rates ..interactions were not possible to be adjusted

the PBF and access to water (category 1); (ii) proportion of total population covered by the PBF and access to sanitation (category 2); (iii) proportion of target population covered by the PBF (category 2) and access to water (category 2); (iv) coverage of the access to water (category 1 and 2) and collection of solid waste.

The effects identified were statistically significant even after adjusting the regression models, considering the zero-inflated related to outcomes of interest.

\section{Discussion}

The results of the study show that average mortality rates due to diarrhea and malnutrition in children younger than 5 years old, decreased when comparing the years 2006 and 2016, in the observed Brazilian municipalities. The highest mortality declines due to diarrhea occurred in the Southern region, followed by the
Midwestern region. The highest mortality declines due to malnutrition occurred in the Southeastern region.

In contrast, longitudinal analysis of the data shows a concentration of higher average mortality rates due to malnutrition in the Northern, Northeastern and Midwestern regions and due to diarrhea in the Northern region. The results are consistent with the study performed in 2018 by Risse et al. [52].

Improvements in the health conditions of the population can be observed when comparing the results of the current study with others that found average mortality rates due to malnutrition and diarrhea in 2009 [22] and from 2000 to 2015 [53] higher than the results found in the current study. The results of the Binomial Negative regression models suggest a protective effect of the population living in the Northeastern, Southeastern and Southern regions, when compared to the Northern region of the country. However, the regional differences 
remain relevant disfavoring Northern, Northeastern and Midwestern regions. That illustrates the need for public policies tailored for reducing health disparities among Brazilian regions and municipalities.

Between 2006 and 2016, PBF coverage declined for both total population and target population. In the beginning of the period, it was observed a good match between high PBF coverage and high proportion of poorer populations. Subsequent reductions on PBF coverage suggest positive impact of the program on poverty reduction. After 2014, however, successive reductions on PBF coverage of the target population, from 91.4\% (2014) to $71.7 \%$ (2016, the lowest coverage), indicate reduction to access by families in situations of social and economic vulnerability. That can result in setbacks in the improvements for poverty reduction and in incentives for using preventive health care, specially the access to the Family Health Strategy (FHS), with possible consequences to mortality rates. The FHS, an important gateway to primary care in the country, presenting over $85 \%$ coverage since 2014 [54, 55], provides compliance with one of the conditionalities of the PBF. Studies have shown PBF health conditionality to result in positive impacts in morbimortality reduction of malnutrition and diarrhea [22].

Still in relation to the decrease in municipal coverage, the education variable showed proportions of literacy in decline over the years of analysis, contrary to expectations [22, 56-58]. Also, the proportion of households with access to water reduced over the period. That is probably associated with difficulties on maintaining the investment for holding the high coverage existing at the beginning of the period.

Between 2006 and 2016, sanitation coverage increased in all years and regions. However, those coverages have never reached $50 \%$ for the whole country. The high degree of heterogeneity in sanitation coverage has been presented over the period: $15.9 \%$ (Northern region) to 67.7\% (Southeastern region) in 2006 and 25.3\% (Northern region) to $75.2 \%$ (Southeastern region) in 2016. In turn, the variables: proportion of urbanized population, collection of solid waste and municipal per capita income, showed consistent increase between 2006 and 2016, which may be associated with social improvements.

The multivariate model related to mortality due to diarrhea (Table 4) shows results that highlight the importance of high coverage of the target population by the PBF and adequate conditions of access to water, sanitation and solid waste collection in reducing mortality rates due to this disease. In relation to these determinants, studies indicate favorable results of access to conditional cash transfer programs (including PBF), directly reflecting on the improvement in the beneficiary family income and in better health and nutrition conditions $[22,54,59-70]$. Other studies point out how access/non-access to drinking water and sanitation has a strong impact on health and disease processes, whether in the outcomes related to infectious diseases, such as diarrhea, or in the nutritional status of the exposed population [10, 37, 61, 71-83]. In this sense, these policies are important and complementary for improving the quality of life and providing safe environments for child growth and development. However, although the effects of interventions in environmental health and PBF have been addressed in these studies, none of them have assessed the effect of simultaneous presence of the two public policies, relating them to the outcomes mortality by diarrhea and malnutrition.

In this study, the choice of the timeframe for evaluating the effects of public policies, PBF and environmental health, allowed for the exploration of their joint effects. In 2003, the PBF started its activities. It was only in 2006 that PBF consolidated data related to municipal coverage and the target population for the whole country. In 2007, water, sanitation and waste management were regulated by means of Law 11.455 [84], establishing national guidelines for basic environmental health in Brazil.

For mortality due to malnutrition, the interaction models (Table 5) show that the variables of access to sanitation (categories 1 and $2 \times$ category 0 ) and collection of solid waste modified the effect of the variable coverage of the total population by PBF. The results from Table 5 indicate that in very poor municipalities access to sanitation and solid waste collection combined with elevated PBF coverage are not sufficient to reduce average rates of malnutrition mortality.

For mortality due to diarrhea (Table 5), the variables of access to water (category $1 \times$ category 0 ) and access to sanitation (category $2 \mathrm{x}$ category 0 ) modified the effect of the variable coverage of the total population by $\mathrm{PBF}$, resulting in the inversion of the ratio of the average mortality rates observed when only the variable coverage of the total population by the PBF is present. When the interaction of the PBF coverage is analyzed in the target population (category $2 \times$ category 0 ) and access to water (category $2 \mathrm{x}$ category 0 ) this expected effect is observed. The results suggest that municipalities that combine $100 \%$ coverage of the target population by the PBF with coverage of access to water above $85 \%$ have lower average rates of mortality due to diarrhea than municipalities not exposed to those levels of coverage. Finally, there is a change in the effect of the access to water variable (categories 1 and $2 \times$ category 0 ) and the collection of solid waste variable, with a decrease in the average mortality rates due to diarrhea. In view of the above, the interaction models used indicated, for the outcome of 
diarrhea mortality, the simultaneous presence of better coverage of the PBF and access to water and sanitation resulting in decrease in the average mortality rates due to diarrhea, validate the hypothesis of their joint beneficial effects in relation to diarrhea mortality (Fig. 1). (insert Fig. 1).

Several studies have observed that the contribution of socioeconomic variables to the improvement of wellbeing and the subsequent impact on the health status of the poor and extremely vulnerable population groups [21, 22, 33, 38, 54, 66]. For large Brazilian cities and poor population groups in general, the growth in formal employment and the minimum wage produced a significant impact reducing socioeconomic and health inequalities [22]. For small cities and extremely poor population groups, social benefits played a larger role because those municipalities are away from the dynamism of the major economic centers. Therefore, they have been unable to produce enough jobs for reducing structural unemployment and meeting the demands of younger workers. The extremely poor population groups from both big and small cities have very little access to the formal job market, being the last to be hired and first to be sacked from their low-qualified jobs [22]. In this study, the potential confounding variables were treated and controlled for in the regression models, resulting in responses that indicated that the observed changes occurred possibly due to the increase in coverage of the target population by the Bolsa Família Program and environmental sanitation services.

\section{Strengths and limitations of the study}

The main limitations of the current study refer to the use of secondary data and the need to apply interpolation and linear extrapolation methods to estimate annual values for some variables. However, any potential bias, which could have caused a decrease in the real fluctuations of the measures over the years, was minimized by comparing the interpolated and extrapolated data with the real data collected through PNADs [85] and SNIS [86], and verifying compatible measures for these values. The current study has some built-in characteristics that reinforce the validity of its findings. Firstly, only municipalities that presented adequacy of vital statistics data were included, which ensures that the information collected related to mortality due to malnutrition and diarrhea is reliable, increasing its internal validity. Secondly, due to the use of the variable coverage of the target population by the PBF, which is specifically targeted to families in situations of social vulnerability, it was possible to analyze the chances of this group being affected by processes of illness and death due these conditions. In addition, one of the strengths of the study was the possibility, through specific statistical analysis, of assessing all 3467 municipalities participating in the research including 38.137 observations. Even with the zero-inflated characteristic of the response variables, the results reflect the reality of $62.35 \%$ of Brazilian municipalities. Finally, it was possible to obtain stronger evidence related to the significance of the variables due to the use of participant panel data and longitudinal analysis of the data when compared to studies using only cross-sectional data [87]. Through a mixed ecological study it was possible to analyze broad socioenvironmental contexts, information not collected at the individual level [88]. The Negative Binomial generalized linear model of fixed effects with and without inflatedzero modeling was utilized quite effectively, and although it forecasted a number of cases of deaths due to malnutrition and diarrhea slightly lower than the actual sample data (losses of $8.07 \%$ due to malnutrition and $0.24 \%$ due to diarrhea), it allowed for an assessment of the significance of the exposure variables.

\section{Conclusion}

In view of the presented results, the maintenance of the PBF, with full coverage of the target population, combined with universal environmental health policies, for all Brazilian municipalities and with greater attention given to the Northern, Northeastern and Midwestern regions, should be a government priority, as this will provide enhanced beneficial effects on child health. The maintenance and expansion of these programs requires prioritization and planning by the country's federal government to meet the demand, along with municipal authorities, in adapting their health, education and housing structures, in order to allow the beneficiary to be assisted and to comply with the Program's conditionalities.

There is a clear downward trend in the main social protection variables, especially in 2016, indicating need for: (i) the PBF target population is fully covered; (ii) universal public environmental health policies; (iii) increased in the literacy of people aged 15 years and old; (iv) increased population coverage by the FHS, through the strengthening of the Single Health System (SUS), thus allowing for: the construction of safer environments, children survival and the improvement on life quality development.

From a global point of view, the findings of this study indicate the importance of associating different social programs when focusing on combating poverty. Systemic interventions, which at the same time aim at protecting individual or families from poverty associated with precarious environmental conditions, are fundamental for eliminating routes of transmission of infectious and parasitic diseases, reducing child deaths. 


\section{Abbreviations}

AIC: Akaike Information Criterion; BIC: Bayesian Information Criterion; CadÚnico: Single Social Registry of the Federal Government Programs; CCT: Conditional Cash Transfer Program; CID-10: Statistical International Classification Code of Diseases and Health-Related Problems - 10th revision; DATASUS: Department of Informatics of the Single Health System; DRSAI: Diseases Related to Inadequate Environmental Sanitation; FHS: Family Health Strategy; GDP: Gross Domestic Product; IBGE: Brazilian Institute of Geography and Statistics; IPCA: National Extended Consumer Price Index; IRR: Ratio for Incidence Rates; JMP: Joint Monitoring Program; MIS: Social Information Matrix; PBF: Bolsa Família Program; PLANSAB: Basic National Sanitation Plan; PNAD: National Household Sample Survey; SIM: Mortality Information System; SMR: Age-Standardized Mortality Rate; SNIS: National Sanitation Information System

\section{Supplementary Information}

The online version contains supplementary material available at https://doi. org/10.1186/s12889-021-10649-4.

Additional file 1: Table S1. Descriptive measures of mortality rates by years of study and municipalities selected - Region Midwest $(N=302)$. Table S2. Descriptive measures of mortality rates by years of study and municipalities selected - Region Northeast $(N=1.163)$. Table S3. Descriptive measures of mortality rates by years of study and municipalities selected - Region North $(N=188)$. Table S4. Descriptive measures of mortality rates by years of study and municipalities selected - Region Southeast $(N=1.037)$. Table S5. Descriptive measures of mortality rates by years of study and municipalities selected - Region South $(N=777)$

\section{Acknowledgements}

Not applicable.

\section{Authors' contributions}

AAS participated in the design, construction and analysis of the data, discussion, writing and revision of the manuscript. SAM participated in data analysis, discussion and review of the manuscript. RPS participated in the construction of the database, discussion and review of the manuscript. LH participated in the design, financing, construction and analysis of the data and revision of the manuscript. All authors have read and approved the final manuscript.

\section{Authors' information}

Anelise Andrade de Souza: René Rachou Institute, Fiocruz Minas. Sueli Aparecida Mingoti: Department of Statistics, Federal University of Minas Gerais.

Rômulo Paes-Sousa: René Rachou Institute, Fiocruz Minas. Leo Heller: René Rachou Institute, Fiocruz Minas.

\section{Funding}

"The current study was carried out with the support of the Coordination for the Improvement of Higher Education Personnel - Brazil (CAPES) - Financing Code 001 and support from the René Rachou Institute, Fiocruz Minas".

\section{Availability of data and materials}

The study was carried out using publicly available data, available in the information systems of the Ministry of Health (MS) [41], Ministry of Social Development (MDS) [42] and Brazilian Institute of Geography and Statistics (IBGE) [43] reported in the methods section and data and collection procedures subsection. Most of the data generated and analyzed during this study are included in the body of the manuscript and as supplementary material. Information from data not shown in a table and referenced in the text of the manuscript is publicly accessible in the information systems mentioned above. All the data used in the research, as well as the database produced by the researchers are with the corresponding author and other authors of the manuscript, in addition to being on the platform of the René Rachou Institute, Fiocruz Minas and may be released as needed and upon reasonable request. Links:
MS: http://tabnet.datasus.gov.br/cgi/menu_tabnet_php.htm MDS: http://mds.gov.br/assuntos/bolsa-familia

IBGE: https://www.ibge.gov.br/

\section{Declarations}

Ethics approval and consent to participate

This study was carried out exclusively with secondary and aggregated data, of public access and in accordance with the Resolutions of the National Health Council (CNS) n $n^{\circ} 466 / 2012$ and $n^{\circ}$ 510/2016, dispensing its appreciation by the Institutional Review Board.

\section{Consent for publication}

Not applicable.

\section{Competing interests}

The authors declare that they have no conflicts of interest.

\section{Author details}

${ }^{1}$ René Rachou Institute, Fiocruz Minas, Avenida Augusto de Lima, 1715, Barro Preto, Belo Horizonte, Minas Gerais, Brazil. ${ }^{2}$ Department of Statistics, Federal University of Minas Gerais, Belo Horizonte, Minas Gerais, Brazil.

\section{Received: 3 June 2020 Accepted: 18 March 2021}

Published online: 31 March 2021

\section{References}

1. Rocha S. Poverty upsurge in 2015 and the rising trend in regional and age inequality among the poor in Brazil. Nova Economia. 2019;29(1):249-75. https://doi.org/10.1590/0103-6351/3992.

2. Fael $M$, Teles $L R$, Caminhas DA. Para além da renda. Uma análise da pobreza multidimensional no Brazil RBCS. 2016;31:92.

3. BRASIL. MINISTÉRIO DO DESENVOLVIMENTO REGIONAL. Plano Nacional de Saneamento Básico - PLANSAB - Mais saúde com qualidade de vida e cidadania. Brasília. 2019.

4. Agência Nacional de Águas. OD6 no Brasil: visão da ANA sobre os indicadores/Agência Nacional de Águas. Brasília: ANA; 2019.

5. Carmo ME, Guizardi FL. O conceito de vulnerabilidade e seus sentidos para as políticas públicas de saúde e assistência social. Cad Saúde Pública. 2018; 34:3.

6. Gomes M, Pereira M. Família em situação de vulnerabilidade social: uma questão de políticas públicas. Ciência Saúde Coletiva. 2005;10(2):357-63. https://doi.org/10.1590/S1413-81232005000200013.

7. Heller L, Rezende SC, Cairncross S. Water and sanitation in Brazil: the publicprivate pendulum. Proceedings of the Institution of Civil Engineers. Munic Eng. 2014;167(3):137-45. https://doi.org/10.1680/muen.13.00019.

8. World Health Organization. A conceptual framework for action on the social determinants of health. Geneva: WHO; 2010.

9. Murtha NA, Castro JE, Heller L. Uma perspectiva histórica das primeiras Políticas Públicas de saneamento e de recursos hídricos no Brazil. Ambiente Sociedade. 2015:3:193-210.

10. Bartram J, Cairncross S. Hygiene, sanitation, and water: forgotten foundations of health. PLoS Med. 2010;7:11.

11. George F. Sobre determinantes da saúde. 2011. Available at: <http://bit.ly/2 VZqVke>. Accessed on 15 Apr 2020.

12. Brasil. Lei n. ${ }^{\circ} 10.836$, de 09 de janeiro de 2004. Cria o Programa Bolsa Família e dá outras providências 2004. Acesso em http://www.planalto.gov. br/ccivil_03/_ato2004-2006/2004/lei//10.836.htm.

13. Camargo PC, Pazello ET. Uma análise do efeito do programa bolsa família sobre o desempenho médio das escolas brasileiras. Economia Aplicada. 2014;18(4):623-40. https://doi.org/10.1590/1413-8050/ea388.

14. BRASIL. Lei n.o 10.836, de 09 de janeiro de 2004. Cria o Programa Bolsa Família e dá outras providências. 2004. Acesso em http://www.planalto.gov. br/ccivil_03/_ato2004-2006/2004/lei//10.836.htm.

15. BRASIL. Decreto n.o 9.396, de 30 de maio de 2018. Altera o Decreto n. 5 . 209, de 17 de setembro de 2004, e o Decreto n. ${ }^{7.492}$, de 2 de junho de 2011, para reajustar valores referenciais de caracterização das situações de pobreza e de extrema pobreza e os de benefícios do Programa Bolsa Família. 2018. Acesso em http://www.planalto.gov.br/ccivil_03/_ato2015-201 8/2018/decreto/D9396.htm. 
16. Nascimento S. Reflexões sobre a intersetorialidade entre as políticas públicas. Serv Soc Soc. 2010;101:95-120.

17. Heller L. Saneamento e Saúde. Brasília: OPAS-OMS; 1997.

18. Humphrey JH, Mbuya MNN, Ntozini R, Moulton LH, Stoltzfus RJ, Tavengwa $N V$, et al. Independent and combined effects of improved water, sanitation, and hygiene, and improved complementary feeding, on child stunting and anemia in rural Zimbabwe: a cluster-randomised trial. Lancet. 2019;7.

19. Greene LE, Freeman MC, Akoko D, Saboori S, Moe C, Rheingans R. Impact of a school-based hygiene promotion and sanitation intervention on pupil hand contamination in Western Kenya: a cluster randomized trial. Am J Trop Med Hyg. 2012;87(3):385-93. https://doi.org/10.4269/ajtmh.2012.110633.

20. Vanderslice J, Briscoe J. Environmental interventions in developing countries: interactions and their implications. Am J Epidemiol. 1995;141(2): 135-44. https://doi.org/10.1093/oxfordjournals.aje.a117401.

21. Guanais FC. Efectos combinados de la ampliación de la atención primaria de salud y de las transferencias condicionadas de dinero em efectivo sobre la mortalidad infantil en Brasil,1998-2010. Rev Panam Salud Publica. 2014;36: 65-72.

22. Rasella D, Aquino R, Santos CAT, Paes-Sousa R, Barreto ML. Effect of a conditional cash transfer programme on childhood mortality: a nationwide analysis of Brazilian municipalities. Lancet. 2013;382(9886):57-64. https://doi. org/10.1016/S0140-6736(13)60715-1.

23. Araújo-Jorge T, Matraca M, Moraes Neto A, Trajano V, Andrea P, Fonseca A. Doenças negligenciadas, erradicação da pobreza e o plano Brazil sem miséria. 1.ed. Brasília: Ministério do Desenvolvimento Social e Combate à Fome; 2014

24. Ministério da Saúde (BR). Secretaria de Vigilância em Saúde. Departamento de Análise de Situação de Saúde. Análise da situação das doenças transmissíveis no Brasil no período de 2000 a 2010. In: Saúde Brasil 2011: uma análise da situação de saúde e a vigilância da saúde da mulher. Brasília: Ministério da Saúde; 2012. p. 46-92.

25. Coutinho JG, Gentil PC, Toral N. A desnutrição e obesidade no Brasil: o enfrentamento com base na agenda única da nutrição. Cad Saúde Pública. 2008;24(suppl 2):332-40.

26. Medronho R, Bloch KV, Luiz RR, Werneck GL, (editor). Epidemiologia. Atheneu, São Paulo, 2009, 2a Edição.

27. Andrade CLT, Szwarcwald CL. Desigualdades sócio-espaciais da adequação das informações de nascimentos e óbitos do Ministério da Saúde, Brazil, 2000-2002. Cad Saúde Pública. 2007;23(5):1207-16. https://doi.org/10.1590/ S0102-311X2007000500022.

28. Szwarcwald CL, Leal MC, Andrade CLT, Souza Júnior PRB. Estimação da mortalidade infantil no Brazil: o que dizem as informações sobre óbitos e nascimentos do Ministério da Saúde? Cad. Saúde Pública. 2002;18(6):172536. https://doi.org/10.1590/S0102-311X2002000600027.

29. Groot R, Palermo T, Handa S, Ragno LP, Peterman A. Cash transfers and child nutrition: pathways and impacts. Dev Policy Rev. 2017;35(5):621-43. https://doi.org/10.1111/dpr.12255.

30. Siqueira MS, Rosa RS, Bordin R, Nugem RC. Internações por doenças relacionadas ao saneamento ambiental inadequado na rede pública de saúde da região metropolitana de Porto Alegre, Rio Grande do Sul, 20102014. Epidemiol Serv Saude. 2017;26(4):795-806. https://doi.org/10.5123/S1 679-49742017000400011

31. Plano Nacional de Saneamento Básico. PLANSAB - Mais saúde com qualidade de vida e cidadania. Brasília: Ministério das Cidades, Secretaria Nacional de Saneamento Ambiental; 2013.

32. UNICEF, WHO. Joint monitoring program. Progress on Drinking Water, Sanitation and Hygiene: 2017. https://www.unicef.org/publications/index_ 96611.html. Accessed Sep 162017.

33. Viana RL, Freitas CM, Giatti LL. Saúde ambiental e desenvolvimento na Amazônia legal: indicadores socioeconômicos, ambientais e sanitários, desafios e perspectivas. Saude soc. [online]. 2016;25:1, p233-246. https://doi. org/10.1590/S0104-12902016140843.

34. Viana RL, Freitas CM, Giatti LL. Saúde ambiental e desenvolvimento na Amazônia legal: indicadores socioeconômicos, ambientais e sanitários, desafios e perspectivas. Saude soc. 2016;25:1.

35. Bezerra TA, Pedraza DF. segurança alimentar entre famílias com crianças menores de cinco anos residentes em área de vulnerabilidade social de Campina Grande, Paraíba, vol. 25; 2015. p. 6.

36. Simões BS, Machado-Coelho GL, Pena JL, Freitas SN. Environmental conditions and prevalence of parasitic infection in Xukuru-Kariri indigenous people, Caldas. Brazil Rev Panam Salud Publica. 2015;38:428.

37. Buhler HF, Ignotti E, Neves SMAS, Hacon SS. Spatial analysis of integrated health and environmental indicators for morbidity and mortality due to infant diarrhea in Brazil, 2010. Cad. Saúde Pública. 2014;30:1921-34.

38. Torres RMC, Bittencourt SA, Oliveira RM, Siqueira ASP, Sabroza PC, Toledo LM. Uso de indicadores de nível local para análise especial da morbidade por diarreia e sua relação com as condições de vida. Ciência Saúde Coletiva. 2013;18(5):1441-50. https://doi.org/10.1590/\$1413-81232013000500029.

39. Souza OF, Benício MHD, Castro TG, Muniz PT, Cardoso MA. Desnutrição em crianças menores de 60 meses em dois municípios no Estado do Acre: prevalência e fatores associados. Rev Bras Epidemiol. 2012;15(1):211-21. https://doi.org/10.1590/S1415-790X2012000100019.

40. Rissin A, Figueiroa JM, Benício MHD, Filho MB. Retardo estatural em menores de cinco anos: um estudo "baseline". Ciência Saúde Coletiva. 2011; 16(10):4067-76. https://doi.org/10.1590/S1413-81232011001100012.

41. Portela RA, Medeiros WSS, Leite VD, Torquato SC. A incidência das doenças diarreicas e a sua relação com a ausência de saneamento: uma revisão bibliográfica. Hygeia. 2011;7:150-6.

42. Kühl AM, Corso ACT, Leite MS, Bastos JL. Perfil nutricional e fatores associados à ocorrência de desnutrição entre crianças indígenas Kaingáng da Terra Indígena de Mangueirinha, Paraná, Brazil. Cad Saúde Pública. 2009; 25(2):409-20. https://doi.org/10.1590/S0102-311X2009000200020.

43. Ministério da Saúde, Departamento de Informática do SUS/DATASUS. SIM. http://www.datasus.gov.br. Accessed 6 Jan 2019.

44. Ministério do Desenvolvimento Social, Matriz de Informação Social. SAGl/ Bolsa Família. https://aplicacoes.mds.gov.br. Accessed 31 Mar 2019.

45. Instituto Brasileiro de Geografia e Estatística, Censos. http://www.ibge.gov.br Accessed 25 Dec 2018.

46. Siqueira MS, Rosa RS, Bordin R, Nugem RC. Internações por doenças relacionadas ao saneamento ambiental inadequado na rede pública de saúde da região metropolitana de Porto Alegre, Rio Grande do Sul, 20102014. Epidemiol. Serv. Saude. 2017;26(4):795-806. https://doi.org/10.5123/S1 679-49742017000400011.

47. Saboia J, Hallak NJ. Salário mínimo e distribuição de renda no Brasil a partir dos anos 2000. Econ Soc. 2018:27:265-85.

48. Cordeiro GM, CGB D. Modelos Lineares Generalizados e Extensões; 2013.

49. Hilbe JM. Negative Binomial Regression. 2nd ed: Cambridge University Press; 2011. https://doi.org/10.1017/CBO9780511973420.

50. Turkman MA, Silva GL. Modelos Lineares Generalizados - da teoria à prática. Lisboa: Edições SPE; 2000.

51. Glantz SA. Primer in biostatistics. 5th ed. New York: McGraw-Hill; 2002.

52. Risse GP, Shibukawa BMC, Goes HLF, Oliveira RR. Crianças menores de 5 anos ainda morrem por desnutrição? Rev Enferm UFPE Online. 2019;13:1-7.

53. Kuiava VA, Perin AT, Chielle EO. Hospitalização e taxas de mortalidade por diarreia no Brazil: 2000-2015. Ciência Saúde. 2019;12:2.

54. Silva ESA, Paes NA. Programa Bolsa Família e a redução da mortalidade infantile nos municípios do Semiárido brasileiro. Ciência Saúde Coletiva. 2019;24(2):623-30. https://doi.org/10.1590/1413-81232018242.04782017.

55. Rasella D, Basu S, Hone T, Paes-Sousa R, Ocké-Reis CO, Millett C. Child morbidity and mortality associated with alternative policy responses to the economic crisis in Brazil: a nationwide microsimulation study. PLoS Med. 2018;15:5.

56. Braga AC, Mazzeu FJC. O analfabetismo no Brazil: lições da história. RPGERevista online de Política e Gestão Educacional. 2017;21(1):24-46. https:// doi.org/10.22633/rpge.v21.n1.2017.9986

57. Haddad S, Siqueira F. Analfabetismo entre jovens e adultos no Brazil. Revista Brasileira de Alfabetização - ABAlf. 2015;1:88-110.

58. Ferraro AR. História inacabada do analfabetismo no Brazil. Rev bras hist educ. 2012;1:28.

59. Silva ESA, Paes NA. Programa Bolsa Família e mortalidade infantil no Brazil: revisão integrativa. HOLOS. 2018;34:201-11.

60. Neto VRP, Berriel CM. Transferências Condicionais de Renda e Nutrição: Efeitos do Bolsa Família nas áreas rurais e urbanas do Brazil. 2017. Economia Aplicada. 2017;21:185-205.

61. Imada KS, Araújo TS, Muniz PT, Pádua VL. Socioeconomic, hygienic, and sanitation factors in reducing diarrhea in the Amazon. Rev Saúde Pública. 2016;50:77.

62. Saldanha LF, Lagares EB, Fonseca PC, Anastácio LR. Estado nutricional de crianças beneficiárias do Programa Bolsa Família acompanhadas pelo Sistema de Vigilância Alimentar e Nutricional no Estado de Minas Gerais. Rev Med Minas Gerais. 2014;24:478-85. 
63. Chagas DC, Silva AAM, Batista RFL, Simões VMF, Lamy ZC, Coimbra LC, et al. Prevalência e fatores associados à desnutrição e ao excesso de peso em menores de cinco anos nos seis maiores municípios do Maranhão. Rev Bras Epidemiol. 2013;16(1):146-56. https://doi.org/10.1590/S1415-790X20130001 00014.

64. Paula DV, Botelho LP, Zanirati VF, Lopes ACS, Santos LC. Avaliação nutricional e padrão de consumo alimentar entre crianças beneficiárias e não beneficiárias de programas de transferência de renda, em escola municipal do Município de Belo Horizonte, Estado de Minas Gerais, Brazil, em 2009. Epidemiol Serv Saúde. 2012;21(3):385-94. https://doi.org/10.5123/S1679-49742012000300004

65. Ranganathan M, Lagarde M. Promoting healthy behaviours and improving health outcomes in low and middle income countries: a review of the impact of conditional cash transfer programmes. Prev Med. 2012;55(suppl): S95-105. https://doi.org/10.1016/j.ypmed.2011.11.015.

66. Paes-Sousa R, Santos LMP, Miazaki LS. Effects of a conditional cash transfer programme on child nutrition in Brazil. Bull World Health Organ. 2011;89(7): 496-503. https://doi.org/10.2471/BLT.10.084202.

67. Gaarder MM, Glassmanb A, Todd JE. Conditional cash transfers and health: unpacking the causal chain. J Develop Eff ect. 2010;2(1):6-50. https://doi. org/10.1080/19439341003646188.

68. Lagarde M, Haines A, Palmer N. The impact of conditional cash transfers on health outcomes and use of health services in low and middle income countries. Cochrane Database Syst Rev. 2009;4:CD008137.

69. Camelo RS, Tavares PA, Saiani CCS. Alimentação, Nutrição e Saúde em Programas de Transferência de Renda: Evidências para o Programa Bolsa Família. EconomiA. 2009;10:685-713.

70. Faria LAN, Pena APSA. Análise do impacto do programa bolsa família em relação ao estado nutricional de crianças de zero a sete anos pertencentes às famílias beneficiárias do programa no município de Pará de Minas, Minas Gerais, no período de 2007/2008. SynThesis Revista Digital FAPAM. 2009;1: 344-54.

71. Mokdad AH. Estimates of global, regional, and national morbidity, mortality, and aetiologies of diarrhoeal diseases: a systematic analysis for the global burden of disease study 2015. Lancet Infect Dis. 2015;17:909-48,

72. Cowman G, Otipo S, Njeru I. Factors associated with cholera in Kenya, 20082013. Pan African Medical Journal. 2017;28:101.

73. Assefa S, Hailu D, Kabeta A, Berhanu G. Household sanitation practice associated with nutritional status of pre-school children aged 24-59 months in Hawassa Zuria Woreda, South Ethiopia: a cross-sectional study. Curr Pediatr Res. 2017;21:291-7.

74. Khalil I, Colombara DB, Forouzanfar MH, Troeger C, Daoud F, Moradi-Lakeh M, et al. Burden of diarrhea in the eastern Mediterranean region, 1990-2013: findings from the global burden of disease study 2013. Am J Trop Med Hyg. 2016;95(6):1319-29. https://doi.org/10.4269/ajtmh.16-0339.

75. Mukabutera A, Thomsom D, Murray M, Basinga P, Nyirazinyoye L, Atwood S, et al. Rainfall variation and child health: effect of rainfall on diarrhea among under 5 children in Rwanda, 2010. BMC Public Health. 2016;16(1):731. https://doi.org/10.1186/s12889-016-3435-9.

76. Deribew A, Tessema GA, Deribe K, Melaku YA, Lakew Y, Amare AT, et al. Trends, causes, and risk factors of mortality among children under 5 in Ethiopia, 1990-2013: findings from the global burden of disease study 2013. Popul Health Metrics. 2016;14(1):42. https://doi.org/10.1186/s12963-0160112-2

77. Njuguna C, Njeru I, Mgamb E, Langat D, Makokha A, Ongore D, et al. Enteric pathogens and factors associated with acute bloody diarrhoea, Kenya. BMC Infect Dis. 2016;16(1):477. https://doi.org/10.1186/s12879-016-1814-6.

78. Fuller JA, Westphal JA, Kenney B, Eisenberg JN. The joint effects of water and sanitation on diarrhoeal disease: a multicountry analysis of the demographic and health surveys. Tropical Med Int Health. 2015;20(3):28492. https://doi.org/10.1111/tmi.12441.

79. Ezek OK, Agho KE, Dibley MJ, Hall J, Page AN. The impact of water and sanitation on childhood mortality in Nigeria: evidence from demographic and health surveys, 2003-2013. Int J Environ Res Public Health. 2014;11: 9256-72.

80. Teixeira JC, Gomes MHR, Souza JA. Análise da associação entre saneamento e saúde nos estados brasileiros - estudo comparativo entre 2001 e 2006. Eng Sanit Ambient. 2011;16(2):197-204. https://doi.org/10.1590/S1413-41522 011000200014

81. Silva RR, Silva CA, Jesus Pereira CA, Carvalho Nicolato RL, Negrão-Corrêa D, Lamounier JA, et al. Association between nutritional status, environmental and socio-economic factors and Giardia lamblia infections among children aged 6-71 months in Brazil. Trans R Soc Trop Med Hyg. 2009;103(5):512-9. https://doi.org/10.1016/j.trstmh.2008.10.019.

82. Teixeira JC, Heller L, Barreto M. Giardia duodenalis infection: risk factors for children living in sub-standard settlements in Brazil. Cad. Saúde Pública. 2007;23(6):1489-93. https://doi.org/10.1590/S0102-311X2007000600024.

83. Barreto ML, Genser B, Strina A, Teixeira MG, Assis AMO, Rego RF, et al. Effect of city-wide sanitation programme on reduction in rate of childhood diarrhoea in Northeast Brazil: assessment by two cohort studies. Lancet. 2007;370(9599):1622-8. https://doi.org/10.1016/S0140-6736(07)61638-9.

84. BRASIL. Lei n.o 11.445, de 05 de janeiro de 2007. Estabelece diretrizes nacionais para o saneamento básico. 2007. Acesso em https://www2.cama ra.leg.br/legin/fed/lei/2007/lei-11445-5-janeiro-2007-549031-normaatualiza da-pl.pdf.

85. Pesquisa Nacional por Amostra de Domicílios, Instituto Brasileiro de Geografia e Estatística, PNAD. http://www.ibge.gov.br. Accessed 07 Feb 2019.

86. Sistema Nacional de Informações sobre Saneamento - SNIS, Ministério do Desenvolvimento Regional. http://www.snis.gov.br. Access 13 Dec 2018.

87. Diez-Roux A. Bringing context back into epidemiology: variables and fallacies in multilevel analysis. Am J Public Health. 1998;88(2):216-22. https:// doi.org/10.2105/AJPH.88.2.216.

88. Susser M. The logical in ecological: I - the logic of analysis. Am J Public Health. 1994;84(5):825-35. https://doi.org/10.2105/AJPH.84.5.825.

\section{Publisher's Note}

Springer Nature remains neutral with regard to jurisdictional claims in published maps and institutional affiliations.

\section{Ready to submit your research? Choose BMC and benefit from:}

- fast, convenient online submission

- thorough peer review by experienced researchers in your field

- rapid publication on acceptance

- support for research data, including large and complex data types

- gold Open Access which fosters wider collaboration and increased citations

- maximum visibility for your research: over $100 \mathrm{M}$ website views per year

At BMC, research is always in progress.

Learn more biomedcentral.com/submissions 